\title{
How Strikes Can Arise: Sequences of Interaction in the Genesis of a Total Strike in Madrid Underground
}

\author{
Nicholas Pohl (Institute of Political Studies, University of Lausanne, Switzerland)
}

This is an original manuscript of an article published by Taylor \& Francis in Social Movement Studies on December 31, 2019, available online:

http://www.tandfonline.com/doi/abs/10.1080/14742837.2019.1708310.

\begin{abstract}
:
Workers' responses to austerity measures during the Great Recession were multiple and diverse. When and why they opted for contentious collective actions instead of reluctant acquiescence is still a subject of debate. In this article, I revisit the issue by examining the genesis of a total strike in Madrid Underground in June 2010, which occurred in response to a wage cut applied to this publicly owned enterprise. By drawing upon union communications produced at the time of the events and semi-directive interviews conducted with union representatives and ordinary workers, I retrace the sequences of interaction between workers, unions, the company management, and the regional government, which eventually led to the total strike. The findings reveal that the question of 'how' is as important as the 'why': the relationship between the wage cut and the strike is in fact anything but direct. Rather, the strike resulted from a largely unintended 'composition effect' - a combination of nested interactions between multiple and interdependent players.
\end{abstract}

Keywords:

Strikes, Labor Movements, Great Recession, Austerity, Interactionism, Spain

In May 2010, the Spanish government decreed a five per cent wage cut for public officials. A few weeks later, Madrid's regional government extended the cuts to public enterprises of the region. In doing so, the regional government undermined prevailing collective agreements negotiated between unions and managements within these 
companies - among them Madrid Underground. Known for being strike-prone, Madrid Underground workers reacted vigorously: They risked their jobs by neglecting the compulsory minimum services ${ }^{1}$ and went on a total strike that lasted for the duration of two days. For forty-eight hours, Madrid Underground stood completely still, causing major traffic gridlocks in the city center. At first sight, this chain of events seems plausible: After all, why shouldn’t strike-proven workers resort to drastic measures if they suffer severe attacks?

In this article, I argue that behind what appears to be a linear causal chain of events are more complex processes that can only be deciphered by paying closer attention to the interactions between the different players involved. Providing such an insight into the complexity of the emergence of labor struggles - notably in times of crisis - is the aim of this analysis of the genesis of the 2010 total strike in Madrid Underground. I proceed to this task in two mutually conducive ways: First, I avoid a mechanistic thinking in linear causal chains by putting particular emphasis on processual dynamics and on nested interactions between the involved players. Second, I go beyond categorizations such as 'workers, employers, and the state' and show that these groups are not homogeneous but rather characterized by internal conflicts.

For this purpose, I adopt an interactionist perspective and combine insights from social movement studies (Fillieule \& Broqua, forthcoming; Jabola-Carolus et al., 2018; Jasper \& Duyvendak, 2015) with literature on strikes as sequences of interaction (Biggs, 2002; Franzosi, 1995). In line with Biggs (2002), I argue that single strikes can only be understood if we consider the preceding sequences of interaction between the different players involved. In this sense, players such as unions do not interact with 'contexts' or 'structures'; instead, they interact with specific players such as company managements and state representatives (Jasper, 2015). 
According to Elias (1984), these interactions can be considered as taking place within 'configurations.' Following this author, a configuration is defined here as a web of competitive relations between reciprocal dependent players. Configurations might settle in momentary balances of power; yet, they are never static. The web of relations is always under tension and susceptible to minor or major changes, e.g. due to shifting alliances and rivalries. The concept of configuration thus has the merit of dynamically grasping the complexity of the relations between multiple allied and opposed players (Fillieule \& Broqua, forthcoming). Furthermore, the notion invites one to go beyond the analysis of divides between categories such as 'labor,' 'employers,' or 'the state,' and to take into consideration the competitive and interdependent relations within these groups of players. In this article, I follow this approach by paying particular attention to the shifting alliances and divisions between the different unions in Madrid Underground.

The emphasis on interdependence furthermore prevents an overly linear and strategist conception of the processes under study. ${ }^{2}$ In fact, the unforeseeable combinations of interactions between the multiple players produce so-called 'composition effects' (Elias, 1984). These are, by definition, neither fully predictable nor attributable to single players. It is ultimately the attention paid to the interdependence between the different players that should prevent one from placing too much weight on single players:

$[\mathrm{T}]$ he more closely integrated are the components of a composite unit, or in other words the higher the degree of their functional interdependence, the less possible it is to explain the properties of the latter only in terms of the former. (Elias, 1984, p. 72)

In the following section, I first describe the empirical data and emphasize the usefulness of drawing on materials produced in actu, i.e. during the course of the events. The core of this article then addresses the actual genesis of the total strike, or, in other words, the 
sequences of interaction preceding the event. In the conclusion, I suggest the application of an interactionist perspective beyond the study of single cases.

\section{Avoiding Retrospective Illusions by Analyzing Sources Produced In Actu}

The aim to present the genesis of an event such as the total strike in Madrid Underground entails the risk of 'etiologic illusions' (Dobry, 2009), i.e. far too linear reconstructions of causal chains ex-post. This risk is higher when drawing on retrospective materials, in which the involved parties attempt to rationalize and give coherence and consistency to past actions. In order to prevent such a retrospective illusion and following Tacket's (1996) approach, this study mainly draws on union circular letters produced in actu by the seven unions represented in the company's works committee in 2010. Table 1 presents a brief overview of these seven unions and their respective characteristics.

\section{[TABLE 1 (UNIONS) AROUND HERE]}

The examined circular letters are a means of communication available to every union of the company's works committee as well as to the works committee as a whole. Twice a week, the company distributes the most recent circular letters at all workplaces. Since 2008 , the circular letters are furthermore available to the workers through the company's intranet.

For the present research, circular letters are a precious source on many grounds: (1) They allow for including all the unions forming part of the works committee. This would hardly have been possible with other sources such as mass media, where only selected union leaders have a voice and only on limited occasions. (2) The circular letters are a crucial means of communication for the unions because they reach the entire staff and also because the company management reads them. The unions thus use 
them to rally the workers but also to exert pressure on the management. (3) The letters provide insights into the changing standpoints of the different unions as well as an account of interactions. The circular letters can in fact be considered as an antagonistic venue in which the unions compete for the workers' support. In this venue, the unions criticize the company management or (local, regional, and national) governments, but they also argue with each other on issues. The circular letters thus allow for the examination of both 'vertical' interactions (with workers or the company management) and 'horizontal' interactions (between the different unions themselves). (4) Finally, the letters are original testimonies of interactions, unbiased by retrospective accounts. They enable one to grasp moments of friction and uncertainty and ultimately the open-ended nature of the interactions.

Despite the many advantages of circular letters, their analysis also bears some risks. First of all, their content should not be taken at face value. While the anticipation of possible reactions (and notably repudiations) from other unions is likely to introduce a system of checks and balances and thus increase the veracity of the circular letters, the letters still serve the strategic purpose of gaining support among workers — who ultimately vote the unions into (or out of) the works committee. Therefore, these documents should always be analyzed under the premises of inter-union competition. Furthermore, the circular letters are merely one form of interaction among many others. For instance, many formal or informal face-to-face meetings between unions or between unions and the company management took place prior to the total strike. Yet, I am not aware of the existence of original minutes for these meetings.

The period under study begins on 1 January 2010 and ends on 28 June of the same year - the day the last workers' assembly before the total strike took place. Focusing neither on the course nor on the result of the strike helps to further reduce the 
risk of 'etiologic illusions' (Dobry, 2009) and, simultaneously, enables the reader to better relate to the feelings of uncertainty experienced by the workers and union representatives during the days, weeks and months preceding the total strike.

For the period between 1 January and 28 June 2010, I examined a full set of 350 circular letters produced by the unions and the works committee in Madrid Underground. Following a 'structured qualitative content analysis' (Mayring, 2014), I created a subset of 137 circular letters by singling out the ones making explicit mention of at least one other union in Madrid Underground (87), those including at least one reference to the economic crisis (23) and those meeting both previously mentioned criteria (27). Table 2 provides an overview of the circular letters that the different unions published between 1 January and 28 June 2010.

\section{[TABLE 2 (CIRCULAR LETTERS) AROUND HERE]}

The circular letters including references to other unions were selected in order to identify (explicit) inter-union interactions and, consequently, the shifting alliances and quarrels between unions. The circular letters referring to the economic crisis were used to examine crisis-related frames and interactions. I distinguished three types of frames: Problem diagnoses and blame attributions (diagnostic frames), articulations of solutions (prognostic frames), and the rationales for action (motivational frames) if calls for action were expressed (Snow \& Benford, 1988). With respect to crisis-related interactions, I examined horizontal interactions between the Madrid Underground unions by drawing on the twenty-seven crisis-related circular letters with explicit reference to other unions. Furthermore, I included vertical interactions by examining the frequent references to the national and regional governments or to the company management (notably in the form of blame attributions), as well as to Madrid Underground workers (to whom the diagnostic, prognostic and motivational frames 
were directed, see Snow, Rochford, Worden, \& Benford, 1986). In order to produce analyzable data, I dated, credited and summarized all references to other players as well as the crisis-related frames. Finally, I arranged the summaries in a chronological order, so as to situate the interactions and frames and, thereby, facilitate a process-oriented analysis.

The core of the analysis focuses on the period between 12 May and 17 June 2010. On 12 May, the social democratic Prime Minister Zapatero announced a set of austerity measures, including a five per cent wage cut for public officials. On 10 June, the Madrid regional government extended the wage cut to Madrid Underground workers. A week later, on 17 June, the Madrid Underground workers participating in a workers' assembly decided to go on a total strike if the extension of the austerity measures to Madrid Underground was upheld. Only regarding this decisive workers' assembly, of which no minutes exist, I complement the data with semi-directive interviews conducted during nine months of fieldwork among the Madrid Underground workers in 2016 and 2017. The analysis of both the circular letters and the interviews allows for a precise reconstruction of the sequences of interaction, including moments of friction and uncertainty, which eventually led to the total strike.

\section{The Genesis of a Total Strike}

By the beginning of 2010, the economic crisis in Spain was manifest: The country had already gone through six consecutive quarters with negative GDP growth, and the unemployment rates were close to 20 per cent. In comparison, Madrid Underground seemed like an island of the fortunate. The workers had remained unaffected by the economic crisis, and the working conditions had even improved during the first years of crisis: A collective agreement signed in June 2009 stipulated 750 euros annual wage increases for both 2009 and 2010. Furthermore, various wage supplements had been 
integrated into the basic salary, and the annual working time was reduced (Metro de Madrid, 2009). This might explain why, at the beginning of 2010, the economic crisis was an issue that most unions within the company only minimally addressed. Between January and May 2018, only the Workers' Commissions, Labor Solidarity, and the General Union of Workers published separate circular letters on the topic. The Drivers' Union and the Free Union signed a joint circular letter together with the Workers' Commissions and Labor Solidarity but did not comment on the ongoing economic crisis in any separate letter. The remaining two unions - the Technicians' Union and the Stations' Union — did not address the issue at all.

The four unions that had not released a separate circular letter on the economic crisis - the Free Union, the Drivers' Union, the Technicians' Union, and the Stations' Union - are all confined to the company level, and the latter three are further confined to one category (drivers, graduate technicians, or station workers, respectively).

Furthermore, these four unions define themselves as 'politically independent.' In contrast, the Workers' Commissions, the General Union of Workers, and Labor Solidarity consider themselves as 'working class unions.' This seems to explain why these three unions addressed the ongoing economic crisis prior to being directly affected.

\section{Early 2010: Routine Bickering Among Unions}

While the three 'working class unions' had all addressed the economic crisis, they significantly differed in their political conclusions and did not withhold criticism of each other. Labor Solidarity, for instance, considered the Workers' Commissions and the General Union of Workers as an integral part of the problem due to their participation in negotiations with the national government and the employers' association. The latter two unions were referred to as 'trade unions of the regime' (SO 
08.02.2010) ${ }^{3}$ or 'trade unions of the [sphere of] power' (SO 15.04.2010). Yet, at the same time, Labor Solidarity signed a collective circular letter together with the Workers Commissions, the Free Union, and the Drivers' Union (CCOO n.d. [09. or 10.02.2010]). ${ }^{4}$ In this letter, the four unions criticized the social democratic government for its intention to raise the retirement age and adopt cuts in other social benefits. On 11 February, the General Union of Workers replied by stating that it refused to sign the collective circular letter because the other unions had rejected its amendments. In that same letter, the union criticized Labor Solidarity for its double standard, i.e. for labeling both the General Union of Workers and Workers' Commissions as 'trade unions of the regime' and for, shortly after, signing a circular letter together with the Workers' Commissions (UGT 11.02.2010).

Conflicts between unions were not restricted to the interpretation of the current economic crisis. Circular letters of early 2010 also point at open quarrels between the General Union of Workers and Labor Solidarity. In an issue of Labor Solidarity’s newspaper 'Countermarch' (Contramarcha), representatives of the General Union of Workers were depicted as drunks, whereupon the latter union asked Labor Solidarity to 'publicly rectify the baseless accusations and insults [against members of the General Union of Workers] that they disseminate in their "pamphlet CONTRAMARCHA", (UGT 11.02.2010; emphasis in the original). In later letters, Labor Solidarity's actions were described as 'childish' (UGT 22.02.2010) and 'fascistic' (UGT 01.03.2010). More generally, the General Union of Workers deplored the multiplicity of unions within Madrid Underground and stated that only the Workers' Commissions and the General Union of Workers were capable of affronting current societal challenges (UGT 25.02.2010). The open quarrels between the General Union of Workers and Labor Solidarity and the latter's criticism of the 'trade unions of the regime' point at a Madrid 
Underground configuration with various lines of conflict among unions. Yet, nothing indicates that these quarrels were unusual; rather, they can be seen as routine bickering between the multiple and competing unions.

\section{The Royal Decree-Law 8/2010: Uncertainty and an Increasing Isolation of the General Union of Workers}

On 12 May, the social democratic Prime Minister Zapatero announced a series of austerity measures in order to 'consolidate' the national budget. The cuts included restrictions regarding the entitlement for partial retirements, a freezing of most retirement pensions, the cancellation of childbirth allowances, and a wage cut of an average of five per cent for all public employees. This announcement caused a stir among the workers and unions of Madrid Underground. Strictly speaking, Madrid Underground workers are not considered public employees because their working conditions rest upon separate collective agreements. Yet, because of the public ownership of the company, the workers are nevertheless attributed to the public sector. Around this particularity emanated uncertainty regarding whether or not the decreed wage cut would affect the workers of Madrid Underground.

Of all unions within the company, Labor Solidarity was the first to take a stand regarding the announcement of austerity measures. In a circular letter published on 17 May, it denounced 'the government's coward adjustment measures ['ajustazo']' (SO 17.05.2010) and explained that it was not yet clear whether the wage reduction was going to affect publicly financed companies such as Madrid Underground. If this were the case, the union stated, mobilizations had to immediately follow.

During the following days, the Workers' Commissions, the Drivers' Union, the Free Union, and Labor Solidarity published a collective circular letter claiming that 'the aggression suffered by the public employees is sufficiently serious for all unions and the 
works committee to give a unified response to the measures of the government' (CCOO n.d. [most likely 18.05.2010]). On 19 May, the General Union of Workers released a circular letter in which it claimed to 'TELL THE TRUTH ABOUT THE MEASURES' (UGT 19.05.2010, emphasis in the original). The letter-entirely written in capital letters-blamed financial institutions and the Right for having provoked the economic crisis, but it did not address any of the austerity measures announced by the government.

On 24 May, the day the austerity measures were published in the form of a Royal Decree-Law (RDL 8/2010) in the Official Bulletin of the State, four unions released separate circular letters on the topic. The Drivers' Union summarized the decree without taking a stand. It put particular emphasis on the provisions regarding partial retirements and stressed that the cuts in this regard were not going not affect Madrid Underground due to the prevailing collective agreement (SCMM 24.05.2010). The Workers' Commissions also gave an all-clear signal with respect to the partial retirements. Regarding the other measures, the union stated that further information would be provided as soon as the 'degree of impact at the company level' could be assessed (CCOO 24.05.2010). Labor Solidarity described the adopted 'adjustment measures' as a 'legal robbery from the pockets of the workers' that called for a response. It criticized 'the unions of the [sphere of] power' for limiting their mobilizations against this decree to a one-day lasting strike in the public sector (on June 8th) and for still considering the possibility of signing a labor market reform, which would lower layoff costs, increase temporary contracts, foster private pension systems, and raise the retirement age (SO 24.05.2010). In the same letter, the union stated that the only answer was a 'GENERAL STRIKE until the government and the IMF repel their measures' (SO 24.05.2010; emphasis in the original). For its part, the General 
Union of Workers released a circular letter declaring that, 'as expected,' the core measures of the decree were not going to affect Madrid Underground. It further criticized the Workers' Commissions, the Drivers' Union, Labor Solidarity, and the Free Union for 'playing the game of the Right' by misrepresenting multiple aspects of the decree (UGT 24.05.2010). The General Union of Workers called for 'prudence and waiting' but warned that it would use means of pressure — including a general strike — if the government unilaterally imposed a labor market reform. The last union to publish a separate circular letter was the Station's Union. The letter was limited to the partial retirements and stated that this provision was not expected to affect Madrid Underground (SEMM 31.05.2010).

The aforementioned collective circular letter shows that the Workers' Commissions, the Drivers' Union, Labor Solidarity, and the Free Union all rejected Zapatero's austerity measures. The General Union of Workers, for its part, did not explicitly defend the cuts, but it did not criticize them either. During the final week of May, the Workers' Commissions, the Free Union and Labor Solidarity (this time without the Drivers' Union) published another collective circular letter titled 'The political commitment of UGT [General Union of Workers]' (CCOO n.d. [between 24.05.-01.06.2010]) in which they denounced that 'the UGT section in Madrid Underground attaches priority to political directives of its party rather than to the workers' (CCOO n.d. [between 24.05.-01.06.2010]). The General Union of Workers quickly responded. In a letter titled 'A brainless political strategy of Workers' Commissions in Madrid Underground' (UGT 02.06.2010), the union retaliated:

With every day that goes by we are less surprised by the initiatives of $\mathrm{CCOO}$ [Workers' Commissions] representatives in Madrid Underground. Their intention to show the company management that they are capable of controlling and leading the union spectrum in our company leads them, pathetically, to spare no 
opportunity $[\ldots]$ for dragging useless unions, such as Labor Solidarity and the Free Union, into their [the Workers' Commissions'] madness. [...] Labor Solidarity, its only raison d'être being the work releases [as union delegates] and the Free Union, a yellow union invented by a former chief of staff-who is now working in human resources_-aiming at weakening class-based unions.

In the same letter, the General Union of Workers repeated that the national government had adopted many left wing and progressive policies but that the union was going to adopt the necessary measures, not excluding a general strike, if working conditions were to suffer attacks.

All of these letters suggest that the union sections were mostly concerned with the possible consequences of the decree at the company level. After a period of uncertainty, a sense of relief spread: It became clear that the cuts were not going to affect Madrid Underground. Thereafter, none of the unions any longer called for company specific actions. The unions also abstained from joining a general strike of the public sector on 8 June, called for by the Workers' Commissions, the General Union of Workers, and the Public Officials Independent Union (Central Sindical Independiente y de Funcionarios, CSIF) at the national level. The growing awareness about the national government's capacity and readiness to decree austerity measures nevertheless affected the Madrid Underground configuration: It resulted in a more aggressive tone between unions and an increased isolation of the General Union of Workers.

\section{A Rupture in the Moral Economy: The Cuts Extended to Madrid Underground}

On 10 June, the Government Council of the Community of Madrid - governed by the conservative People's Party (Partido Popular) — presented a draft bill with urgent application measures for the Royal Decree Law 8/2010. While the decree explicitly excluded publicly owned enterprises, the Government Council of the Community of 
Madrid suddenly suggested their inclusion, making explicit reference to Madrid Underground.

The day after, three unions addressed the decision in separate circular letters. The Free Union informed about the new situation and called for a workers' general assembly on 17 June when 'we [the Madrid Underground workers] will decide about the means of pressure that we consider appropriate' (SLMS 11.06.2010) in order to defend the collective agreement. In its letter, Labor Solidarity asserted that the workers of Madrid Underground would 'not remain quiet while they [the members of the regional government] rob us five per cent of our salary' (SO 11.06.2010). Apart from a general strike against the RDL 8/2010 and the imminent labor market reform, the union called for Madrid Underground specific mobilizations in the defense of the collective agreement: '[W]e will propose to the unions with which we have already been working in unity (the Drivers' Union, the Workers' Commissions and the Free Union) the celebration of an urgent general assembly' (SO 11.06.2010). The General Union of Workers qualified the regional government's plans as 'illegal' because they violated the constitutional right of collective bargaining (UGT 11.06.2010). On 14 June, the Stations' Union also released a circular letter arguing that the wage reduction plans and the violation of collective agreement made a 'strong response' necessary (SEMM 14.06.2010).

The announcement of the regional government annulled clauses of the collective agreement signed a year before by the works committee and the company management — notably, the stipulated wage increases for 2009 and 2010. This sudden extension of the austerity measures to the workers of Madrid Underground was unexpected and resulted in outrage among the unions. By violating the collective agreement in effect, the regional government undermined the foundations of collective 
bargaining. The message was not only a 'moral shock' (Jasper, 1997) but was also considered a betrayal of the common rules for the settlement of disputes. According to these rules, a collective agreement was binding and — if at all—any modifications would always have to go through a collective bargaining process that included the works committee. Viewed in this in light, the regional government's unilateral implementation of a wage cut undermined the reciprocity and guarantees of prior routinized exchanges. In other words, it resulted in what can be considered a rupture in the 'moral economy' (Thompson 1971) between the workers, the unions, the company management, and, ultimately, the regional government.

Even though there was now a shared opposition to the wage cuts among unions in Madrid Underground, it did not bridge longstanding divides: In a circular letter on 14 June, the Workers' Commissions criticized that 'some unions' (most likely referring to the 'politically independent' unions) within Madrid Underground had thought they had nothing in common with public officials and that 'some union' in particular (clearly referring to UGT) had even justified the cuts of the national government (CCOO 14.06.2010). In a subtler manner, the General Union of Workers condemned Labor Solidarity for its last circular letter, in which it had explained that there was unity only between Labor Solidarity, the Workers' Commissions, the Drivers' Union, and the Free Union, leaving aside the General Union of Workers. Criticizing this statement, the General Union of Workers argued that 'there must not exist the slightest crack in the union unity' in regard to the imminent wage cut (UGT 14.06.2010).

The regional government's decision also brought other players to the forefront of the Madrid Underground configuration: The criticisms in the circular letters no longer targeted a distant central government; instead, they were directed toward a more palpable regional government and its subordinate bodies. The unions indeed urged to 
convene meetings with the Chief Executive Director (who is appointed directly by the president of the Community of Madrid) and the Managing Director (who is appointed by the Chief Executive Director) prior to the workers' general assembly on 17 June.

One day before the workers' general assembly, the General Union of Workers presented the decisions made the same day by the permanent commission of the works committee. The unions had agreed on two rallies: the first on 24 June, when the amendments to the bill were going to be voted in the Assembly of Madrid, and the second on 28 June, when the final bill was voted. Furthermore, strikes were proposed for 28-30 June. According to the General Union of Workers, all unions were in favor of a 24-hour lasting strike on 28 June. For the two remaining days, the Workers'

Commissions and the Free Union apparently wanted to leave the decision regarding the scope of the strike to the workers' general assembly (UGT 16.06.2010).

The rupture in the moral economy due to implementation measures of the regional government thus resulted in a shared opposition among the unions in Madrid Underground. Yet, while the unions worked together and called for action, they did not agree on the magnitude of the actions to take. All seemed to depend on the workers' assembly on 17 June, where the workers had to decide about the specific actions to undertake.

\section{Outbidding for Revenge: How the Collective Alignment Occurred}

The circular letters published after the workers' general assembly show that a meeting held with the company board the day before the assembly had ended without any result. The Chief Executive Director had not attended the meeting, and the rest of the company board apparently 'did not know [about] or did not want to expound on' the matter (SEMM 17.06.2010). The day of the assembly, another meeting took place, this time in the presence of the Chief Executive Director, though again without 'any sort of 
clarification' (SLMS 18.06.2010). The players representing the government's decision were visibly unwilling or not allowed to engage in any dialogue, let alone reach a compromise. This total refusal made mediation impossible and contributed to escalating the conflict.

What exactly occurred thereafter, during the workers' general assembly? In order to complement the circular letters published the day after the assembly, I turn to interviews conducted with workers and union representatives during two fieldwork stays in Madrid in 2016 and 2017.

Oscar, a driver and member of the Drivers' Union who was 34 years old in 2010, described the morning assembly ${ }^{5}$ as follows:

I went to the assembly because I had heard that it was going to be heated, and [when I got there] the hall was full to bursting point. It was completely overcrowded and, well, the unions started working the crowd. [...] One after the other [stated], 'I overbid, I overbid.' [...] Marcos Pereira from the Workers' Commissions held a fervid talk. Then, Pedro Romero from the Drivers' Union did the same. Initially, the Drivers' Union was not in favor [of a total strike]. As far as I know, their premise was not to ignore the minimum services. [In other words], they came with this stance in their minds but, during the assembly, they got carried away. They, as well as all the rest of the unions, all entered the game.

Through this quote, various aspects of the assembly become visible: (1) The imminent wage cut had stirred up emotions not only among union representatives but also among the workers, who expected a 'heated assembly. ${ }^{6}$ In order to understand the course of the assembly, one has to bear in mind the (angry) workers and the tense atmosphere that resulted from their coming together, by filling the assembly room 'to the bursting point.' (2) Some speakers seem to have played crucial roles. The fact that, six years after the event, Oscar still points at certain individuals, indicates that they have left a lasting impression on him. (3) It seems that the assembly was rapidly characterized by 
an outbidding competition — notably among union representatives — which caused speakers to drift away from their initial positions.

Regarding the atmosphere during the assembly, Oscar offered this comment:

Everyone asked: 'Who?' [shouting:] 'Barabbas! Barabbas! Barabbas! ${ }^{7}$ This is how it was - a moment of heated tempers ['calentón']. Yes, it was demeaning to take away five per cent [of our salary], and something similar had never happened before. Of course, we were angry and very outraged. But, [...] if the assembly had been calmer, perhaps we would not have been able to achieve that [to approve the total strike].

Mario - a station worker and former Labor Solidarity union representative who was 51 years old in 2010 — described the evening assembly in similar (though more skeptical) terms:

I didn't like the atmosphere of the assembly. [...] I didn't like it because it was very euphoric. But [it was] euphoria [...] like [that experienced] at a soccer game. It came across as [euphoric tone:], 'Let's go! Let's tear this down!' [It was] as if nobody had done any reflecting.

The workers were visibly angry. Similar to the union representatives, they felt the regional government and the company management had betrayed them. The coming together of the workers seemed to potentiate their anger. By collectively expressing their fury - as in a soccer game - the workers (also those who did not rise to speak publicly) took an active part in the dynamic of the assembly.

It is with this heated atmosphere in mind that one can understand how the union representatives became involved in an outbidding competition. Eduardo-a technician and Labor Solidarity representative who was 52 years old in 2010 - explains how his union became involved in the dynamic: 
What happened at the assembly? Well, Soli [common abbreviation used for Labor Solidarity] wasn't suggesting these strikes. You'd be surprised, but Soli didn't plan any strikes of this kind. [...] We were pushed to support them. [...] Marcos Pereira took the floor and said, 'Nothing, no minimum services, nothing! That's enoughwe're going to shut down Madrid Underground!' Martín [another Labor Solidarity representative] was at the speaker platform and turned to me: 'Eduardo, what do we do? Who expected this to happen?' [Directed toward the interviewer:] Look at the mess we ran into: A guy [...] who comes up and makes this suggestion. People applauding. For that time, it was quite a well-attended assembly. I [said] to Martín, 'Well, Martín, what can we do? We have to go for it. We'll see. Let's see what happens.' See, this is how Soli got into this difficult situation ['pastel'].

By suggesting the total strike, Marcos Pereira from the Workers' Commissions set a new course. As explained by Oscar, Pedro Romero from the Drivers' Union was the first to express his support. Both these speakers were respected union representatives of the two major unions in Madrid Underground. The massive roars of applause for the two speakers indicate that organizational allegiances were fading among the workers present at the assembly. This in turn increased the pressure on the representatives of other unions, which were left with little choice but to join in the call. The result was a 'collective alignment' (Ermakoff, 2008) behind a call for strike exceeding the scope of all previously expressed claims by any single union.

Whether or not Marcos Pereira had premeditated his speech remains a matter of speculation. However, it is clear that his speech only constituted the initial spark of a process that rapidly became beyond his control. He could not anticipate with certainty how the workers would receive the message, nor did he know whether successive speakers would take up the proposition and support it. What later became the most debated Spanish workers' resistance since the outbreak of the Great Recession should thus not be considered as a result of a well planned and thought out decision of a homogeneous group (e.g. 'the workers' or 'the unions'). Rather, it was a 'composition 
effect' (Elias, 1984) resulting from nested interactions between multiple and interdependent players - union representatives and workers alike.

This is not to say that the players were acting irrationally. Eduardo's quote suggests that the union representatives understood that they were facing a 'critical decision' (Ermakoff, 2008, 2017). Eduardo and his union representative fellow seem to have been startled by the dynamic of the assembly precisely because they understood that a decision to go on a total strike would be highly consequential, involve individual risks and 'substantially alter the cost structure of subsequent options' (Ermakoff, 2017, p. 131). Yet, the quote also points at a union representative caught of guard; one who did not see any viable alternative to joining in the call for a total strike. On the workers' side, the massive attendance indicates that many workers were determined to exercise their decisional power - and they eventually did by uniting the unions and voting in favor of the total strike.

\section{Stalemate and Hesitant Unions: The Period between 17 June and 28 June}

The workers' assembly on 17 June was the decisive sequence in the decision to go on a total strike. The day after the assembly, all union sections, with the exception of the Technicians' Union, published a circular letter with respect to the assembly. They all underscored the unity reached among workers and unions. This points at an increasingly polarized Madrid Union configuration: On the one side, the regional government and its subordinate bodies, which were not willing to negotiate, let alone reverse the wage cut. The workers and unions, on the other side, which had closed ranks in their fight against the austerity measure.

All the circular letters stated that the two rallies (on 24 June and on 28 June) had been confirmed and that three 24-hour strikes for 28-30 June had been approved. In its circular letter, Labor Solidarity commented on the decision (SO 17.06.2010): 
The assembly has decided to legally carry out the strike on 28 June, respecting the minimum services. But, if [on] this day, the Assembly of Madrid adopts the decree which overrides our collective agreement, signed exactly a year ago, we too are going to break the rules of the game ['rompemos la baraja'], and the strike will be total, locking ourselves up in our venue in Plaza de Castilla [where the workers' assemblies take place] from that same evening onwards.

This excerpt supports the above-presented hypothesis concerning a rupture in the moral economy. Because the company and the regional government did not uphold their side of the deal, workers and unions considered that they too were legitimated to disregard their obligations. Like the bread rioters in the seventeenth and eighteenth centuries, who aimed at restoring the traditional price setting standards for bread (Thompson, 1971), the workers and union representatives at Madrid Underground aimed at reestablishing collective bargaining as the authoritative conflict resolution process.

While the other circular letters included similar arguments, they were not as explicit regarding the nature of the adopted strikes. The Workers' Commissions alluded to the total strike by mentioning that they did not consider Madrid Underground as an essential service $^{8}$ (CCOO 18.06.2010). The Stations' Union invoked the decision in an even subtler manner, writing 'paro' when referring to the strike on 28 June and 'huelga' when referring to the strikes on 29-30 June, thus hinting at a widespread distinction between a limited work stoppage ('paro') and more resolute strike ('huelga') (SEMM 17.06.2010). The Drivers' Union did not refer to the minimum services but declared that on the occasion of its upcoming membership assembly, it would propose 'to maintain or extend' the decision of the workers' general assembly. Both the General Union of Workers and the Free Union did not make any direct or indirect allusion to a possible total strike. Thus, of all of the unions, only Labor Solidarity openly communicated what was going to become a reality a few days later. 
At the same time, mass media entered the configuration. From 18 July onwards, all major Spanish newspapers extensively covered the imminent total strike. Union representatives (particularly of the three major unions, i.e. the Drivers' Union, the Workers' Commissions, and the General Union of Workers) were constantly asked to justify the assembly's decision. They repeatedly stated that the total strike would only be revoked if the cuts affecting Madrid Underground were withdrawn. Under these circumstances, backpedalling on the part of the unions would have implied a considerable loss in credibility: The attendance at the assembly had been too massive, ${ }^{9}$ its decision too unanimous, ${ }^{10}$ and the unions (especially the major ones) too often had to publicly defend and reinforce the assembly's decision. None of the major unions took this risk. Only the two smallest unions - the Technicians' Union and the Stations' Union - came forward a few days later and stated that they did not form part of the strike committee (Technicians' Union) or that they withdrew from it (Stations' Union). Yet, in both cases, the argument put forward was not a disagreement with the assembly's decision, but an apparent lack of consideration by the other unions (SEMM 21.06.2018; STMM 22.06.2018).

Thus, the only apparent option to call off the strike was an amendment to the bill, which would have resulted in excluding Madrid Underground from the cuts. Yet, contrary to the peasants of the seventeenth and eighteenth centuries, who could count on the support from the 'paternalist tradition of the authorities' (Thompson, 1971, p. 79) in order to undo illegitimate price increases for bread or flour, Madrid Underground workers could not expect any support from the conservative regional government. What is more, the authority was here itself the aggressor-one that was all too eager to put austerity measures in the public sector into effect and was prone to overlooking the 
moral claims of the workers. The result was a Madrid Underground configuration characterized by a stalemate and increasingly entrenched, antagonistic positions.

Despite the menace of a total strike and the massive rallies in front of the regional parliament on 24 June and 28 June, the bill passed on 28 June and the cuts were to be applied to Madrid Underground. In the evening of 28 June, right after the regional parliament's final vote, the workers came together for another workers' assembly. No speaker questioned (or dared to question) the decision made at the last assembly. Without any additional formal vote, the workers and union representatives split into smaller groups and began to organize the pickets, which had to enforce the coming days' total strike. ${ }^{11}$

\section{Discussion and Conclusions}

In this article, I retraced the genesis of what became the most debated workers' resistance since the outbreak of the Great Recession in Spain: a total strike in Madrid Underground that lasted two days in June 2010. I applied an interactionist perspective (Biggs, 2002; Fillieule \& Broqua, forthcoming; Jasper \& Duyvendak, 2015) and examined the precise sequences of interaction, which eventually led to this strike. These sequences were retraced mainly on the basis of an analysis of 350 union circular letters produced between 1 January 2010 and 28 June of the same year - the last day before the total strike.

The discerned sequences can be described as follows: During the first sequence, the Madrid Underground configuration was characterized by 'routine bickering' among unions and the economic crisis was a topic rarely addressed in the unions' circular letters. The second sequence began on 12 May when the social democratic central government announced austerity measures for the public sector. This sequence was marked by uncertainty regarding the applicability of the measures to Madrid 
Underground workers, whose working conditions were stipulated in a separate collective agreement. The uncertainty was accompanied by an increasing isolation of the General Union of Workers, which—as the only major union—did not distance itself from the government. The third sequence started on 10 June, when the Madrid regional government extended the cuts to Madrid Underground. With this decision, the regional government undermined the foundations of collective bargaining. It also reshaped the Madrid Underground configuration by uniting the unions in a shared resistance against the regional government's decision. Yet, while moving together, the unions did not reach a common stance regarding the appropriate actions to take in order to ward off the impending wage cut. The fourth sequence is limited to the decisive workers' assembly on 17 June, during which union representatives and workers converged in a call for a total strike — a call exceeding all previously expressed claims by any single union. As I could show, the 'collective alignment' (Ermakoff, 2008) resulted from a largely unintended 'composition effect' (Elias, 1984): A combination nested interactions, which took the form of an outbidding competition among union representatives, interrupted by massive roars of applause from the workers. The result was a final sequence marked by a stalemate and increasingly entrenched positions within the Madrid Underground configuration: On the one side, the regional government and its subordinate bodies, which were not willing to negotiate, let alone reverse the wage cut. On the other side, the major unions, which were pushed to publicly defend (and reinforce) the workers' decision, making any kind of backpedalling virtually impossible. The number of circular letters referring to the economic crisis reflects the escalation of the conflict (see Figure 1).

[FIGURE 1 AROUND HERE]

Methodologically, this research stresses the usefulness of drawing on materials 
produced in actu. These allow for a close examination of processes and dynamics, including moments of friction and uncertainty, and help to avoid overly linear reconstructions ex-post (Dobry, 2009). The circular letters' value is further increased by the fact that they provide an account not only of vertical interactions (between unions and the company management or regional government) but also of horizontal exchanges (between different unions).

The present analysis is a call to pay attention not only to the causal factors for collective action (the 'why') but also to the actual processes that lead to action (the 'how'). I argue that it is through a close look at the sequences of interaction that one is able to identify both the crucial players and the critical moments in the emergence of contentious collective actions. Such a focus could prove a valuable contribution to recent initiatives bridging social movement studies with studies on 'critical junctures" ${ }^{12}$ (Della Porta, 2018). Including sequences of interaction preceding protest events could in fact help further debunk the 'inevitability' (Dunning, 2017) — or its counterpart, the 'spontaneity' (Flesher Fominaya, 2014) —often ascribed to those massive protest events triggering critical junctures.

This research was limited to a sequential analysis of the genesis of one single strike. I agree with other scholars (Fillieule \& Broqua, forthcoming; Jasper \& Duyvendak, 2015) that an interactionist perspective can and should also be applied to longer and broader sequences. Yet, when increasing the scope, it becomes more difficult to include the diversity of players involved and some higher degree of abstraction and homogenization inevitably follows. An interactionist perspective has nevertheless the merit of not aiming at identifying the 'main players' a priori. Rather than on the basis of predefined models, the players to take into account are discerned through an examination of their significance in particular configurations. This also allows for 
consideration of the shifting importance of players, since they can move to the forefront during some sequences but fade into the background during others.

Ultimately, however, I argue that it is precisely the confined temporal and organizational scope of this study that produced promising avenues for future research. The close look at the shifting alliances and quarrels between unions, for instance, enabled to discern an ambiguous relationship between inter-union competition and the escalation of industrial conflict. Inter-union competition was in fact crucial both to the containment of the conflict during the initial sequences and to the (escalating) outbidding between union representatives during the decisive workers' assembly. Yet, further research is needed in order to understand why inter-union competition contributes to escalating industrial conflicts in some instances, but favors the containment of such conflicts in others. More broadly, future research could examine the extent to which the dynamic described in this article applies to geneses of other contentious collective actions that are jointly called by multiple players. Such research would set out to examine the precise configurations and situations in which rather openended initial sequences shift into sudden (and potentially unintended) collective alignments, which then become points of no return.

\section{Endnotes}

\footnotetext{
${ }^{1}$ In Spain, services contributing to the fulfillment of constitutional rights fall into the category of 'essential services.' For these services, freedom of strike is limited, and minimum services are decreed (Vivero Serrano, 2002). Because public transports are considered to guarantee the constitutional right of freedom of movement, they too have to be operating at a 'minimum level' during strike periods. Depending on the expected ridership, the decreed minimum services for Madrid Underground generally vary between 40 and 60 per cent of the standard operation.
} 
${ }^{2}$ While the interactionist perspective presents evident advantages, it also bears the risk of 'hodiecentrism' (Duyvendak \& Fillieule, 2015) — an analytical focus limited to the present. Limiting oneself to sequences of interactions during short timespans indeed runs the risk of forgetting that players pre-exist these precise interactions: each player has its own history, which strongly shapes its (conceivable) options for action. While I am aware of this risk, the limited scope of this article does not allow me to provide full historical accounts of the different players involved. Where possible, I still provide historical substance to the processes and players under study.

${ }^{3}$ All citations from circular letters and later from interviews are my own translations.

${ }^{4}$ Although signed by four unions, this and later collective circular letters are attributed to the union which finally issued it. The fact that the circular letter was handed in by the Workers' Commissions suggests that this union was also the letter's initiator.

${ }^{5}$ Due to the multi-shift operation in Madrid Underground and in order to enable workers' meeting attendance, the workers' assemblies are always two-part: One session begins in the morning (10 a.m.), and the other in the evening (6 p.m.). Attendance is generally higher in evening sessions due to less overlap with shift or rest hours (e.g. after night shifts).

${ }^{6}$ Due to lack of data, I am unable to reconstruct the interactions between rank-and-file workers and their union representatives prior to the assembly. It thus remains unclear whether and to what extent rank-and-file initiatives or upsurges in the run-up to the assembly have affected the course of the latter.

${ }^{7}$ Referring to an episode of the gospels, where the crowd shouts in favor of commuting Barabbas' instead of Jesus' death sentence.

${ }^{8}$ For which minimum services are decreed, see Note 1.

${ }^{9}$ The numbers regarding the attendance varied between 'more than 1,000' (SO 17.06.2010), 1,050 (CCOO 18.06.2010) and 'more than 1,200' (UGT 18.06.2010). The most precise number was given by Labor Solidarity, which specified that 328 workers had attended the morning and 694 workers had attended the evening assembly (SO 17.06.2010). This corresponds to a total of 1022 workers of 7624 employees overall (Metro de Madrid, 2010).

${ }^{10}$ I.e. 'virtually by unanimity' (UGT 18.06.2010) or with only two dissenting votes and one abstention (CCOO 18.06.2010).

${ }^{11}$ Whether the total strike can be considered a success is a matter of interpretation. During the strike, the company management refused to negotiate. After forty-eight hours of total 
standstill, the workers - many of whom feared harsh reprisals, including layoffs — gave in and decided to resume the minimum services in order to allow negotiations to begin. Four more strike days and numerous meetings between the strike committee and the company management followed. At a workers' general assembly on 17 July, the majority of attendees finally accepted a preliminary agreement supported by the majority of the strike committee (Drivers' Union, Workers' Commissions, General Union of Workers and the Free Union), but opposed by Labor Solidarity. The agreement retained the five per cent cut in personnel costs. Yet, by reducing personnel costs other than wages (e.g. professional training related expenses or by not filling job vacancies) the cut in actual wages could be limited to one percent.

${ }^{12}$ 'Critical junctures' being defined here as periods of 'crisis or strain that existing policies and institutions are ill-suited to resolve' (Roberts, 2015, p. 65).

\section{References}

Biggs, M. (2002). Strikes as Sequences of Interaction: The American Strike Wave of 1886. Social Science History, 26(3), 583-617.

Della Porta, D. (2018). Protests as Critical Junctures: Some Reflections Towards a Momentous Approach to Social Movements. Social Movement Studies. DOI: $10.1080 / 14742837.2018 .1555458$

Dobry, M. (2009). Sociologie des crises politiques. Paris: Les Presses de Sciences Po. Dunning, T. (2017). Contingency and determinism in research on critical junctures. Qualitative \& Multi-Method Research, 15(1), 41-47.

Duyvendak, J. W., \& Fillieule, O. (2015). Patterned Fluidity: An Interactionist Perspective as a Tool for Exploring Contentious Politics. In J. M. Jasper \& J. W. Duyvendak (Eds.), Players and Arenas: The Interactive Dynamics of Protest (pp. 9-32). Amsterdam: Amsterdam University Press.

Elias, N. (1984). What Is Sociology? New York: Columbia University Press. 
Ermakoff, I. (2008). Ruling Oneself Out: A Theory of Collective Abdications. Durham: Duke University Press.

Ermakoff, I. (2017). Shadow Plays: Theory's Perennial Challenges. Sociological Theory, 35(2), 128-137.

Fillieule, O., \& Broqua, C. (forthcoming). Sexual and Reproductive Rights Movements and Counter Movements from an Interactionist Perspective. Social Movement Studies.

Flesher Fominaya, C. (2015). Debunking Spontaneity: Spain's 15-M/Indignados as Autonomous Movement. Social Movement Studies, 14(2), 142-163.

Franzosi, R. (1995). The Puzzle of Strikes: Class and State Strategies in Postwar Italy. Cambridge England; New York: Cambridge University Press.

Jabola-Carolus, I., Elliott-Negri, L., Jasper, J. M., Mahlbacher, J., Weisskircher, M., \& Zhelnina, A. (2018). Strategic Interaction Sequences: The Institutionalization of Participatory Budgeting in New York City. Social Movement Studies. DOI: $10.1080 / 14742837.2018 .1505488$

Jasper, J. M. (1997). The Art of Moral Protest: Culture, Biography, and Creativity in Social Movements. Chicago: University of Chicago Press.

Jasper, J. M. (2015). Introduction: Playing the Game. In J. M. Jasper \& J. W. Duyvendak (Eds.), Players and Arenas: The Interactive Dynamics of Protest (pp. 9-32). Amsterdam: Amsterdam University Press.

Jasper, J. M., \& Duyvendak, J. W. (Eds.). (2015). Players and Arenas: The Interactive Dynamics of Protest. Amsterdam: Amsterdam University Press.

Mayring, P. (2014). Qualitative Content Analysis: Theoretical Foundation, Basic Procedures and Software Solution. Klagenfurt: Beltz.

Metro de Madrid. (2009). Convenio Colectivo 2009-2012. Madrid: Metro de Madrid. 
Metro de Madrid. (2010). Informe Anual 2010. Madrid: Metro de Madrid.

Pohl, N. (2016). Quand les hiérarchies reviennent par la fenêtre... La démocratie au sein d'un syndicat anarcho-syndicaliste. IEPHI Working Paper Series, 65, 1-116.

Roberts, K. (2015). Changing Course in Latin America: Party Systems in the Neoliberal Era. Cambridge: Cambridge University Press.

Snow, D. A., \& Benford, R. D. (1988). Ideology, Frame Resonance, and Participant Mobilization. International Social Movement Research, 1(1), 197-217.

Snow, D. A., Rochford, E. B., Worden, S. K., \& Benford, R. D. (1986). Frame Alignment Processes, Micromobilization, and Movement Participation. American Sociological Review, 51, 464-481.

Tackett, T. (1996). Becoming a Revolutionary: The Deputies of the French National Assembly and the Emergence of a Revolutionary Culture (1789-1790). Princeton: Princeton University Press.

Thompson, E. P. (1971). The Moral Economy of the English Crowd in the Eighteenth Century. Past \& Present, 50, 76-136.

Vivero Serrano, J. B. (2002). La huelga en los servicios esenciales. Valladolid: Lex Nova.

Winston, C. M. (1982). The Proletarian Carlist Road to Fascism: Sindicalismo Libre. Journal of Contemporary History, 17(4), 557-585.

\section{Acknowledgments}

I am grateful to Olivier Fillieule, Philippe Gottraux, James Jasper and Marie Métrailler for their invaluable and constructive comments on earlier drafts of this paper. I would also like to express my gratitude to the anonymous reviewers as well as to the editors of this journal both for their thorough reviews and for their guidance in preparing this manuscript for publication. 


\section{Author links}

Social Media Profiles: https://unil.academia.edu/NicholasPohl,

https://www.researchgate.net/profile/Nicholas-Pohl-2

\section{Disclosure statement}

No potential conflict of interest was reported by the author.

\section{Funding}

This work was supported by the Swiss National Science Foundation P1LAP1_178066.

\section{Notes on contributor}

Nicholas Pohl is a PhD candidate in political sociology at the University of Lausanne (IEP-CRAPUL). His thesis deals with industrial conflict between 2000-2016 in Spain and aims at bringing labor back into social movement studies. He is co-supervised by Professor Olivier Fillieule, University of Lausanne, and Professor Christine Walley, MIT Anthropology.

\section{ORCID}

Nicholas Pohl http://orcid.org/0000-0002-2877-3713 
Table 1. Madrid Underground unions and their respective characteristics; ordered according to the number of seats held in the company's works committee in 2010.

\begin{tabular}{|c|c|c|c|c|c|}
\hline & $\begin{array}{l}\text { Spanish name and } \\
\text { acronym }\end{array}$ & $\begin{array}{c}\text { No. of } \\
\text { seats in } \\
\text { works } \\
\text { committee }\end{array}$ & $\begin{array}{l}\text { Organizational form and scope of union } \\
\text { membership }\end{array}$ & $\begin{array}{l}\text { Self-reported political } \\
\text { stance }\end{array}$ & Strike-proneness $^{\mathrm{a}}$ \\
\hline Drivers' Union & $\begin{array}{l}\text { Sindicato de Conductores } \\
\text { de Metro de Madrid; } \\
\text { SCMM }\end{array}$ & 8 & $\begin{array}{l}\text { Union confined to Madrid Underground; } \\
\text { organizing train drivers only }\end{array}$ & 'Politically independent' & $\begin{array}{l}\text { Calling strikes only if the working conditions of drivers } \\
\text { are concerned. }\end{array}$ \\
\hline $\begin{array}{l}\text { Workers' } \\
\text { Commissions }\end{array}$ & $\begin{array}{l}\text { Comisiones Obreras; } \\
\text { CCOO }\end{array}$ & 7 & $\begin{array}{l}\text { Union section of one of the two major } \\
\text { Spanish trade unions; organizing all } \\
\text { underground workers }\end{array}$ & $\begin{array}{l}\text { 'Working class union,' } \\
\text { historically close to the } \\
\text { communist left }\end{array}$ & $\begin{array}{l}\text { Engaged in many labor struggles within Madrid } \\
\text { Underground. }\end{array}$ \\
\hline $\begin{array}{l}\text { General Union } \\
\text { of Workers }\end{array}$ & $\begin{array}{l}\text { Unión General de } \\
\text { Trabajadores; UGT }\end{array}$ & 6 & $\begin{array}{l}\text { Union section of one of the two major } \\
\text { Spanish trade unions; organizing all } \\
\text { underground workers }\end{array}$ & $\begin{array}{l}\text { 'Working class union,' } \\
\text { historically affiliated with } \\
\text { the social democratic party }\end{array}$ & $\begin{array}{l}\text { Controversial role in labor struggles within Madrid } \\
\text { Underground, especially due to the signing of a partial } \\
\text { agreement (limited to the union's membership) during the } \\
\text { negotiation of a collective agreement in 1998. The } \\
\text { Workers' Commissions and Labor Solidarity considered } \\
\text { this action as a 'stab in the back.' }\end{array}$ \\
\hline $\begin{array}{l}\text { Labor } \\
\text { Solidarity }\end{array}$ & $\begin{array}{l}\text { Confederación Sindical } \\
\text { Solidaridad Obrera; SO }\end{array}$ & 5 & $\begin{array}{l}\text { Major union section of a small, } \\
\text { nationwide trade union; organizing all } \\
\text { underground workers }\end{array}$ & 'Anarcho-syndicalist' & $\begin{array}{l}\text { The most strike-prone union in Madrid Underground, } \\
\text { having repeatedly called strikes without any further union } \\
\text { backing. }\end{array}$ \\
\hline Free Union & $\begin{array}{l}\text { Sindicato Libre Metro y } \\
\text { Suburbano; SLMS }\end{array}$ & 4 & $\begin{array}{l}\text { Union confined to Madrid Underground; } \\
\text { organizing all underground workers }\end{array}$ & 'Politically independent ${ }^{\mathrm{c}}$ & $\begin{array}{l}\text { Considers workers and the company management as } \\
\text { partners and is thus rather strike adverse. }\end{array}$ \\
\hline $\begin{array}{l}\text { Technicians' } \\
\text { Union }\end{array}$ & $\begin{array}{l}\text { Sindicato de Técnicos de } \\
\text { Metro de Madrid; STMM }\end{array}$ & 2 & $\begin{array}{l}\text { Union confined to Madrid Underground, } \\
\text { organizing graduate technicians only }\end{array}$ & 'Politically independent' & $\begin{array}{l}\text { Strike adverse due to the proximity of its constituency with } \\
\text { the company management. }\end{array}$ \\
\hline Stations' Union & $\begin{array}{l}\text { Sindicato de Estaciones de } \\
\text { Metro de Madrid; SEMM }\end{array}$ & 1 & $\begin{array}{l}\text { Union confined to Madrid Underground, } \\
\text { organizing station workers only }\end{array}$ & 'Politically independent' & $\begin{array}{l}\text { Calling strikes only if the working conditions of station } \\
\text { workers are concerned. }\end{array}$ \\
\hline
\end{tabular}

${ }^{a}$ the assessment of strike-proneness is difficult and ventured, especially if reduced to one sentence. Yet, this information is nevertheless important in order to understand the interactions prior to the total strike. It also reveals the prevailing factionalism, which had to be overcome (or at least temporarily set aside) to make the strike possible.

${ }^{\mathrm{b}}$ Resulting from a split from another anarcho-syndicalist union called General Confederation of Labor (Confederación General del Trabajo, CGT) in 1990 (see Pohl, 2016).

${ }^{\mathrm{c}}$ Its homonym of the 1920s and 1930s, however, had its origins in the traditionalist right and aimed at building a trade union counter power to the anarcho-syndicalist

Confederación Nacional del Trabajo (Winston, 1982, p. 562). 
Table 2. Number of circular letters published between 1 January 2010 and 28 June

2010; sorted by union and tag.

\begin{tabular}{|c|c|c|c|c|c|}
\hline & $\begin{array}{l}\text { Inter-union } \\
\text { interaction }\end{array}$ & Crisis-related & $\begin{array}{c}\text { Inter-union } \\
\text { interaction } \\
\text { and crisis- } \\
\text { related }\end{array}$ & No tag & $\begin{array}{c}\text { Total circular } \\
\text { letters per } \\
\text { union }\end{array}$ \\
\hline Drivers' Union & 6 & 4 & 0 & 21 & 31 \\
\hline Workers' Commissions & 3 & 4 & 0 & 48 & 55 \\
\hline General Union of Workers & 28 & 4 & 8 & 24 & 64 \\
\hline Labor Solidarity & 18 & 7 & 8 & 41 & 74 \\
\hline Free Union & 3 & 2 & 1 & 56 & 62 \\
\hline Technicians' Union & 8 & 0 & 1 & 5 & 14 \\
\hline Stations' Union & 2 & 2 & 1 & 18 & 23 \\
\hline Collective circular letters ${ }^{\mathrm{a}}$ & 4 & n.a. & 3 & n.a. & 7 \\
\hline Works' committee $^{b}$ & 15 & n.a. & 5 & n.a. & 20 \\
\hline Column total & 87 & 23 & 27 & 213 & 350 \\
\hline
\end{tabular}

a The collective circular letters were signed by the Workers' Commissions, Labor Solidarity, the Free Union and, in all except one case, also by the Drivers' Union. All collective circular letters refer to inter-union interactions, which is why the tags 'crisis' and 'no tag' do not apply.

${ }^{\mathrm{b}}$ Circular letters published by the works committee are generally approved by all the unions, but need at least a simple majority of all the members to be published as such. All circular letters by the works committee refer to inter-union interactions, which is why the tags 'crisis' and 'no tag' do not apply. 


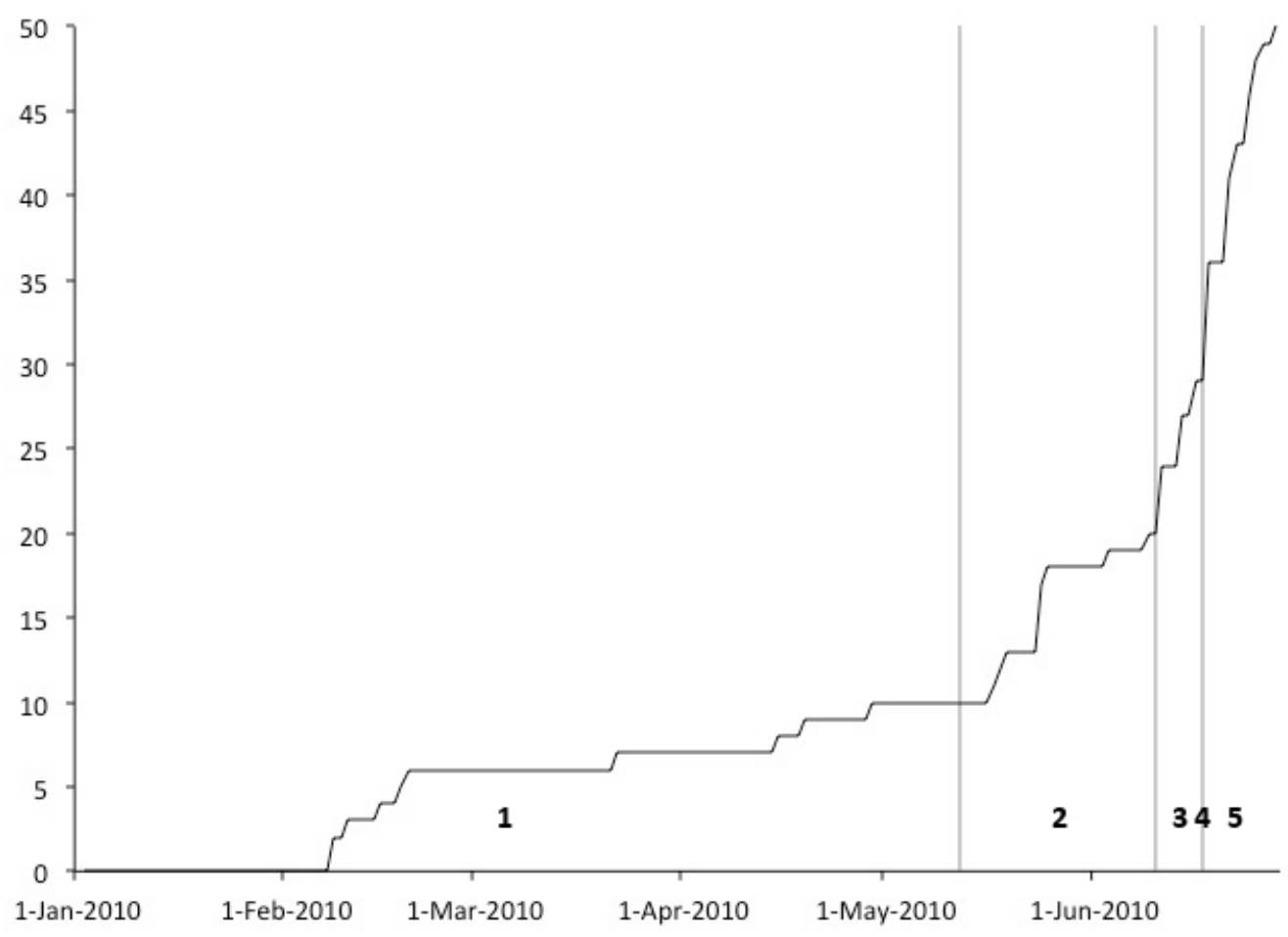

Figure 1. Total number of crisis-related circular letters published between 1 January 2010 and 28 June 2010. The five sequences are separated by grey lines, sequence 4 being a grey line only. 